\title{
Analysis Of Science Humanistic Teaching Skills For Preservice Elementary School Teachers
}

\author{
Sudarto $^{1}$, Rosmalah ${ }^{2}$ \\ \{drsudartompd@gmail.com ${ }^{1}$ \} \\ ${ }^{1,2}$ Universitas Negeri Makassar (Makassar State University), Indonesia
}

\begin{abstract}
The purpose of this research was perceive the level of science humanistic teaching skills for elementary school preservice teachers. The research method used was survey method. The participants of this research were the preservice teachers of Elementary School Teacher Education Program, Education Science Faculty of Makassar State University. Data collection techniques used was questionnaire by instrument questionnaire sheet. The analyzing data technique was using 2007 Excel program. The research results show that, in general, from eight humanistic teaching skills that involved in this resarch, the preservice teachers have owned five of them, namely: (1) giving motivation to the students to take part in learning, (2) giving motivation to the students to do the tasks, (3) guiding the students patiently in make the students understanding to the subject matter, (4) guiding the students patiently in make the students completing the task, and (5) directing the students lovingly to focus on learning. Therefore, in general, it can be concluded that the preservice teachers have owned five or $62.5 \%$ of science humnistic teaching skills. Whereas, the three or the $37.5 \%$ humanistic teaching skills that were not owned by the preservice teacher yet, in general covered: (1) giving different task according to the abilities of the students in intelligent, (2) showing two or more ways in make the students understanding the subject matter and (3) showing two or more ways in make the students completing the task.
\end{abstract}

Keywords: science, humanistic teaching skills, elementary schools, preservice teachers, students.

\section{Introduction}

Science is organized and systematic knowledge of the material world (David, 2010). Other definition, science is the investigation and interpretation or events in the natural, physical environment and within our bodies (Carr). Science includes a body of knowledge, process for conducting inquiry, and ways of thingking reflected in the tenets that underprint the nature of scientific knowledge (Goldston Downey, 2013). By all the defintions, we can say that Science is the body of knowledge about world that structures in organized 
and sistematic, the process for conducting inqury or investigate the natural, and thingking reflected.

Science is very important for everyone, so everyone ought to master the science as early as possible. Bidwell (The Eclectic Magazine of Foreign Literature, Science, and Art. Vol. 17, 21, and 84) says that science helps us to understand better and more wisely all the activities of the world around us. The statment is suitable with the statment of Prof. Ian Chubb-former Chief Scientist of Australia in one time in his speech that says, "We all need science, in the sense that our lives would be intolerable without it" (University of Technology Sidney. Why do we need Scienc? [Power Point Slides]).

Becase Science is very important, we all ought to master it in mening that if we are science teachers, we must have varied strategies to make undestand the studens abou science, and if we are students, we must attempt to conceive it. However, there are some facts show that Science is a field of study that is generally regarded difficult by students. Various studies have been carried out by various parties, especially by researchers to overcome the difficulties. Yet, the results of researchs until now show that the science study field is still considered difficult by students. The difficulties for example accurs because the mismatch teaching strategies used by teachers are in conflict with students' natural learning styles or their preferences for certain instructional psocedures (Kempa, 1991). Furthermore, he says that it is important for science teachers and educators to recognize and respond to the various causes of students' learning difficulties.

According to Witt JD., Archer L , \& Moote J. (2018), the influence of the cultural arbitrary of physics (as a part of science) which leads many students to conclude that physics (as a part of science) is not 'for me' and hence choose other paths. Ogunkola and Samuel (2011) say that it is important for educators and curriculum development officials to have an understanding of the reasons why so many students in the school (especially the lower secondary school) say that science is a difficult subject and quickly lose interest in it. The other opinions about why students feel difficult in learning science are statments by Johnstone (1991) and Millar (2008)]. They say that the difficulties of learning the sciene subject are related to the nature of the science itself and the methodes that is used by teacher in teaching science. Finally, they find that one reason by many causes why the sudents feel difficult in learning science is the strategy that is used by teachers make them boring with very little effort being made to present the subject matter in an interesting and relevant way.

From the views above, it can be seen that the reasons why the students feel difficult in conceiving science is the lack of teachers' humanistically in teaching science. This lack of specialist teacher science makes students feel stiff and awkward if they can not be said to be afraid to learn the science. Science as a subject or study material requires a varied thinking abilities which certainly requires a comfortable and joyful atmosphere-not a frightening atmosphere.

Based on a survey that is conducted in several elementary schools in Tanete Riattang District of Bone Regency from February to November 2018, researchers concluded that elementary school teachers were less in humanistic teaching in making students learn in the school. At the same time, researches observate too the science abilitis of some elementary school students from the above area. Researchers find that the science abilitis of the students are very poor, it means that the students curtain feel difficult in learning science. 
By all the views above, researches conclude that the students' difficulties in learning science is caused by the learning strategy using science teacher that far from humanistically. However, it needs to be further investigated to recognize clearly the finding. In order to be more focused, researchers explore the humanitically of elementary school preservice teachers in teaching Science or Science themes at the schools involved above. Preservice teachers are chosen in this research by two reasons: the strategies that using by them at the time they take practice to teach not far from the strategies using by the teachers where they teach and the humatiscally of them must be investigate before they be a realy teacher or leave the campus.

Based on the explanation above, researhers propose a solution to overcome the problem, namely humanistic learning strategy. Researchers believe that this strategy can make the students happy to learn the science and furthermore make them unfeel difficult again to the science.

Hence, the problem formulation of this research is: How is the level of science teaching skills humanistic of elementary school preservice teachers? Based on this problem formulation so the purpose of this research is perceive the level of science teaching skills humanistic of elementary school preservice teachers. From the research result, we can make decisions pertein the follow-up that can be given to the preservice teachers in connection how to make the student unfeel difficult to the science subject and further be an inspiration for need or not providing a training about science teaching skills humanistic to the other elementary school preservice teachers and/or elementary school real teachers.

The science humanistic teaching skills of elementary school preservice teachers must be perceived because it is very related to the strategy in teaching science so the science be delighting by students that for end impact to the regarding that Science is not difficult and the end ecstatically not difficult (be convenient). This result can influence the subtlety related about the handling that must be taken to increase the science abilities of the students.

The preservice teachers must seize teaching skills humanistic in order to they can easily engage the humanistic strategy in teaching science. Humanstic strategy is a straetgy in education that aims to develop human potential and forms a good personality (Firdaus \& Mariyat, 2018). Further, they say that the implication of humanistic approach in education is how to the educators encourage students to think critically and act according to the values of humanity so it can produce a good learner and critical of reality. Likewise, Sharp (2012) says that the primary goal of a humanistic education is human well-being, including the primacy of human values, the development of human potential, and the acknowledgment of human dignity. Chen and Schmidtke (2017) says that including humanistic elements in educational practice will enable instructors to be more effective in helping students to develop skills in relation to team work, problem-solving, systems improvement, lifelong learning and other areas that are becoming increasingly necessary for success in the workplace. These statements are supported by Kae Hwa \& Ju (2015) who says that the humanitic approach that is conducted by nursing students in serving patients when practicing can improve the communication skills of the nursing students. In alignment with this statement, Shiau \& Chen (2008) say that approach used in humanistic care, it does so for the purpose of allowing the health professional to understand and apply the concepts of humanistic value in their services.

According to Roode (2016), a humanistic approach implies a central concern for sustainable human and social development, in which the fundamental purpose of education should be to sustain and enhance the dignity, capacity and welfare of the human person in 
relation to others and to nature. Lei (2007) in Allameh , Sarem, and Hamidi (2013) say humanistic approach emphasizes the importance of the inner world of the learner and places the individual's thought, emotions and feelings at the forefront of all human development. A humanistic approach in education can make the personal relation between teacher and students. This relation is very important because the scare which maybe exist in the sutdents' hirt will lost immediately. This is in alignment with the statement Al-Khalidi (2015) that by philosophist, humanistic is based on the idea that close personal relationships give meaning to the whole process of teaching and learning.

Constance (1996) says that the humanistic approach is something which is very important in understanding the human. So, if the humen beings involved in the world of education had been had the humanistic character so the main elements of education which cover teacher, school, and learning activity will be better. This is understandable because the real core of these elements is the teacher. It means that if the teacher is decent so the others will obey to be decent, too.

Actually, humanistics learning approach is very related with the student center learning approach and this issue is very support the opinion of Kember (1997) in Sue Tangney (2014) who says that there had been a change in conceptions about learning systems, namely from content-oriented learning to student-centered learning or orientation concepts in student learning. Regarding the student-centered learning oriented, Lynch (2016) says that philosophy of student-centered is about how to the teachers make a focus on the students' needs so the teachers must assist and teach them within the classroom ensuring the level of students' success or their intellegence. In alignment with this statement, American Psychological Association (1997, paragraph 12) says as follow:

Educators need to help students examine their learning preferences and expand or modify them, if necessary. The interaction between learner differences and curricular and environmental conditions is another key factor affecting learning outcomes. Educators need to be sensitive to individual differences, in general. They also need to attend to learner perceptions of the degree to which these differences are accredited and adapted to by varying instructional methods and materials.

The above statements also in a line with opinion that one criterion of teacher's profesional qualities is know the different levels of the students' intelectual and emotional maturity (Linkedin Learning, https://www.slideshare.net/missy1727/principles-of-teaching). Therefore, humanistis teachers in the school will give birth the humanitic students and the humanitic students will be students that like the Science. Indeed, school is the best arena for further teacher development (Postholm, 2012) and the humanistic school surely will mold teachers and students of science lovers.

Based on all the explanations about humanistisc aproach or other humanistis views above, it seen that the main skills that must be had by all the science teachers or sciencce educators is about "how to make the students learn the science". In this research, about "how to make the students learn the science", reseacher choose "how to make encouraging to the students in order to they learn continuely in the learning process in class" is made into indicatotor of the humanistis teaching skills. 


\section{Method}

This research uses a survey method. A survey method is the method that is conducted to collect data about individuals or a group of individuals in terms of issues relating opinions, attitudes, skills, or others at one point in time by using questionnaire forms (Lavrakas, 2008 \& A Briggs, Coleman \& Morrison (2012) The participants of this research are the preservice teachers of Elementary School Teacher Education Program, Science Education Faculty of Makassar States University. There are ten preservice teachers that involved in this research.

Data in this research is collected by using questionnaire sheet and the analyzing data technique is using excel program. Data collecting are about the humanistic teaching skills about how to the pre-service teachers (PST) or participants make encouraging to the students in order to they learn continuely in the learning process. This indicators consist of eigt sub indicators as show in Table 1. The implementation of each teaching aspect activities or sub indicators is about the frequence of the participants in conducting all the activities or all sub indicators that involve three categories: Yes (Y), Seldom (S) and Never (N). In all these activities or sub indicators we hope the "Yes" categori is the highest. In other words, the higher "Yes" categori is the better. And, in analysing the data, only "Yes" categori in implementation about the indcators that be said as humanistic teaching skils that is owned by the preservive teachers under the condition that the "Yes" categori of the indicators over of $50 \%$.

Table 1 Indicator and Sub Indicators of The Humanistic Teaching Skills

\begin{tabular}{|c|c|}
\hline Indicators & Sub Indicators \\
\hline \multirow{8}{*}{$\begin{array}{l}\text { Encouraging the students } \\
\text { to learn continuely }\end{array}$} & (1) Giving motivation the students to take part in learning \\
\hline & (2) Giving motivation the students to do the tasks \\
\hline & $\begin{array}{l}\text { (3) Showing two or more ways in make the students } \\
\text { understanding the subject matter }\end{array}$ \\
\hline & $\begin{array}{l}\text { (4) Showing two or more ways in make the students completing } \\
\text { the task }\end{array}$ \\
\hline & (5) Directing the students lovingly to focus on learning \\
\hline & $\begin{array}{l}\text { (6) Guiding the students patiently in make the students } \\
\text { understanding the subject matter }\end{array}$ \\
\hline & $\begin{array}{l}\text { (7) Guiding the students patiently in make the students } \\
\text { completing the task }\end{array}$ \\
\hline & $\begin{array}{l}\text { (8) Giving different task according to the abilities of the students } \\
\text { in intelligent }\end{array}$ \\
\hline
\end{tabular}




\section{Results and Discussion}

In this section, the results that are presented are about the implementation of each aspect of teaching activities that become indicator of the humanistic teaching skills in this research. The indicator is about how to the pre-service teachers (PST)/participants make encouraging to the students in order to they learn continuely in learning. The indicator consist of some sub indicators as show in Table 1 above. The implementation of each teaching aspect activities or the sub indicators is about the frequence of the participant in conducting all the activities that involve three categories: Yes (Y), Seldom (S) and Never (N). In indicators of humanistic teaching skills we hope the "Yes" categori is the highest. In other words, the higher "Yes" categori is the better. And, in analysing the data, only "Yes" categori in implementation about the indcators that be said as humanistic teaching skils that is owned by the preservive teachers under the condition that the "Yes" categori of the indicators over of 50\%.

The data about the implementation of each teaching activities aspect or all the sub indicators are collected with using questionnaire sheet. The questionnaire results are shown in Table 2 .

Table 2 The Questionnaire Result of PST in Encouraging the Students to Learn Continuely

\begin{tabular}{|c|c|c|c|c|}
\hline \multirow[t]{2}{*}{ Indicator } & \multirow[t]{2}{*}{ Sub Indicators } & \multicolumn{3}{|c|}{$\begin{array}{l}\text { Implementation } \\
(\%)\end{array}$} \\
\hline & & $\mathrm{Y}$ & $\mathrm{S}$ & $\mathrm{N}$ \\
\hline \multirow{8}{*}{$\begin{array}{l}\text { Encouraging the } \\
\text { Students to Learn } \\
\text { Continuely }\end{array}$} & (1) Giving motivation the students to take part in learning & 80 & 10 & 10 \\
\hline & (2) Giving motivation the students to do the tasks & 80 & 10 & 10 \\
\hline & $\begin{array}{l}\text { (3) Showing two or more ways in make the students understanding } \\
\text { the subject matter }\end{array}$ & 30 & 60 & 10 \\
\hline & $\begin{array}{l}\text { (4) Showing two or more ways in make the students completing the } \\
\text { task }\end{array}$ & 30 & 60 & 10 \\
\hline & (5) Directing the students lovingly to focus on learning & 70 & 10 & 20 \\
\hline & $\begin{array}{l}\text { (6) Guiding the students patiently in make the students } \\
\text { understanding the subject matter }\end{array}$ & 80 & 10 & 10 \\
\hline & $\begin{array}{l}\text { (7) Guiding the students patiently in make the students completing } \\
\text { the task }\end{array}$ & 80 & 10 & 10 \\
\hline & $\begin{array}{l}\text { (8) Giving different task according to the abilities of the students in } \\
\text { intelligent }\end{array}$ & 20 & 50 & 30 \\
\hline
\end{tabular}


If the data in Table 2 are plotted in a graph so it is shown as the Figure 1 below.

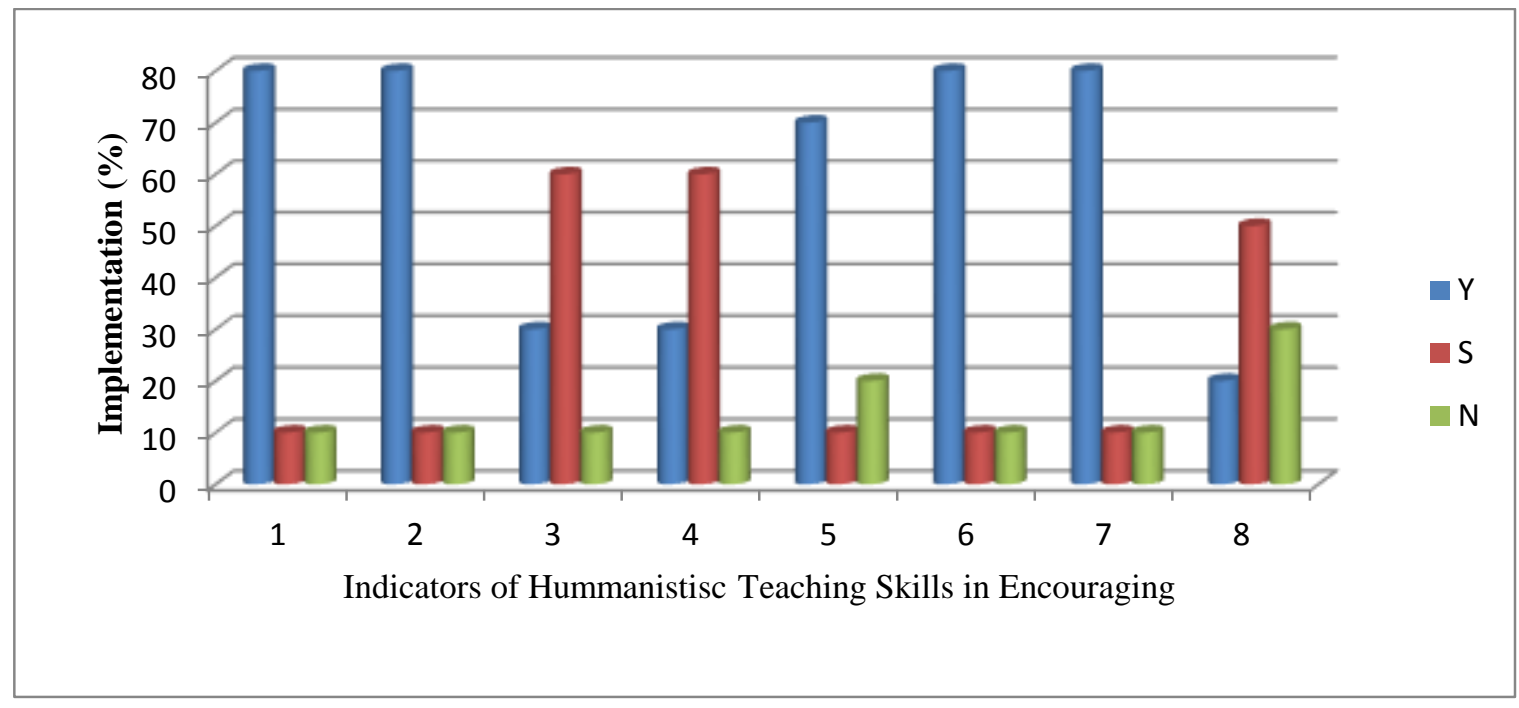

Figure 1 The Questionnaire Result of PST in Encouraging the Students to Learn Continuely

As can be seen in Table 2 and/or Pigure 1, the sub indicators about giving motivation to the students to take part in learning, giving motivation to the students to do the tasks, guiding the students patiently in make the students understanding to the subject matter, and guiding the students patiently in make the students completing the task are the sub indicators that the most participants conduct them because on each this sub indicator there are $80 \%$ participants conduct it. It means that there are $80 \%$ of participant always conducts the sub indicators when they were teaching the sciene. It means too that the rest of it, namely $20 \%$ do not always. As can be seen in Table 2 and/or Pigure 1 above, the $20 \%$ participant is divided in to two: $10 \%$ seldom and $10 \%$ never conducting. The next sub indicator that many participants conduct it is directing the students lovingly to focus on learning. For this sub indicator, there are $70 \%$ participants that conduct it, $10 \%$ seldom and $20 \%$ never. As for, the sub indicators that the least participants conduct it is giving different task according to the abilities of the students in intelligent. In this sub indicator, only $20 \%$ participants conducted while $50 \%$ seldom and $30 \%$ never. The next sub indicators that only a little participants (under 50\%) conduct them are showing two or more ways in make the students understanding the subject matter and showing two or more ways in make the students completing the task. For each this sub indicators, only $30 \%$ participants that conduct them. The rest of each this sub indicator, $60 \%$ seldom and $10 \%$ never.

The research results above show that there are $80 \%$ of preservice teachers conduct four activities as indicators of humnistic teaching skills. The four activities are : (1) giving motivation to the students in order to to take part in learning, (2) giving motivation to the students to do the tasks, (3) guiding the students patiently in make the students understanding to the subject matter, and (4) guiding the students patiently in make the students completing the task. It means that almost all the preservice teachers have been had humanistic teaching skills about how to motivate the students in order to always follow the learning and finish the 
tasks and about guiding the students in order to they always attempt to understand the subject matter and complete their tasks. All this humanitis teaching skills are very important to be had by the educators in order to they can motivate or encourage the students. This is in alignment with opinion of Fauzan Akmal Firdaus and Akrim Mariyat (2018) who say that the implication of humanistic approach in education is how to the educators encourage students to be a good learner. If the teachers or educators had been obtained mold good leaners so they had been obtained mold science lover. This is one of the ideals of humanitic science teachers.The next activity as indicators of humnistic teaching skills that there are a lot of participants who conduct it is "directing the students lovingly to focus on learning". For this activity, there are $70 \%$ of preservice teachers who conduct it. This activity as an indicator of humnistic teaching skills is very important too to be had by the theachers or educators because this activity or skills can create a good relationships with the students. The close relationships between the teacher and students is very relate with the statement of Nasiema Mustafa Sadeq Al-Khalidi (2015) that close personal relationships give meaning to the whole process of teaching and learning.

As for, the sub indicators that only a little preservive teachers (under of 50\%) that conduct them are "giving different task according to the abilities of the students in intelligent", "showing two or more ways in make the students understanding the subject matter" and "showing two or more ways in make the students completing the task". It means that only a little preservive teachers who conduct the three indicators as long as they teaching sciene in the class. Even though, these three activities as indicators of humnistic teaching skills also very important to be had by the teachers. This fact is contradict whith the student-centered learning oriented. Regarding the student-centered learning oriented, Matthew Lynch (2016) says that Philosophy of student-centered is about how to the teachers make a focus on the students' needs so the teachers must assist and teach them within the classroom ensuring the level of students' success or their intellegence. The fact also contradict with the statement of American Psychological Association (1997) that says, educators need to be sensitive to individual differences and they also need to attend to learner perceptions of the degree to which those differences are accredited and adapted to by varying instructional methods and materials. Also, contradict with the opinions about that one criterion of teacher's profesional qualities by all criterions is know the different levels of the students' intelectual and emotional maturity (Linkedin Learning, https://www.slideshare.net/missy1727).

Therefore, by the results research above, it can be concluded that the humanistic teaching skills of the preservice teacher, in general are: 1) giving motivation to the students to take part in learning, (2) giving motivation to the students to do the tasks, (3) guiding the students patiently in make the students understanding to the subject matter, (4) guiding the students patiently in make the students completing the task, and (5) directing the students lovingly to focus on learning. It means too that in general, the preservice teachers have owned five or $62.5 \%$ humnistic teaching skills.

Whereas, the humanistic teaching skills that is not owned by the preservice teacher yet, in general there are three: (1) giving different task according to the abilities of the students in intelligent, (2) showing two or more ways in make the students understanding the subject matter and (3) showing two or more ways in make the students completing the task. It means too that in general, the preservice teachers have not owned yet five or $37.5 \%$ humnistic teaching skills. 


\section{Conclusion}

Therefore, by the results research and discussion above, it can be concluded that the humanistic teaching skills that are have been owned by the preservice teachers that involved in this research, in general are: 1) giving motivation to the students to take part in learning, (2) giving motivation to the students to do the tasks, (3) guiding the students patiently in make the students understanding to the subject matter, (4) guiding the students patiently in make the students completing the task, and (5) directing the students lovingly to focus on learning. Therefore, in general, the preservice teachers have owned five or $62.5 \%$ humnistic teaching skills. Whereas, the humanistic teaching skills that is not owned by the preservice teacher yet, in general there are three: (1) giving different task according to the abilities of the students in intelligent, (2) showing two or more ways in make the students understanding the subject matter and (3) showing two or more ways in make the students completing the task. Therefore, in general, the preservice teachers have not owned yet five or $37.5 \%$ humnistic teaching skills.

\section{Acknowledgments}

The authors thank to the preservice teachers who have be participant in this research.

\section{References:}

Allameh M. K, Sarem S. N, \& Hamidi H. 2013. Humanistic education: Concerns, implications and applications. Journal of Language Teaching and Research, 4 (1),

$45-$

$$
\text { 51. doi:10.4304/jltr.4.1.45-51. }
$$

Al-Khalidi, Nasiema M. S. 2015. The relationship between humanistic teachers' characteristics practices and students' learning. Global science research journal, 3 (2), 170-174.

Retrieved

http://www.globalscienceresearchjournals.org/gjef/709492015864.pdf

American Psychological Association. 1997. Learner-centered psychological principles: A Framework for school reform. Retrieved from https://www.cdl.org/articles/learner-centered-psychological-principles/

Briggs A. R. J., Coleman M., \& Morrison M. (eds). 2012. Research methods in educational leadership and management, $3^{\text {rd }}$ Edition. SAGE. London. Retrieved from https://books.google.co.id/books?id=kIpohey43eoC\&printsec=frontcover \&hl=id\#v=0 nepage $\& \mathrm{q}=$ survey $\% 20$ researh $\% 20$ is $\& \mathrm{f}=$ false

Carr, Albert B. Science in the Elementary School: A humanistic approach . Retrieved from https://scholarspace.manoa.hawaii.edu/bitstream.

Chen P. \& Schmidtke C (2017). Humanistic elements in the educational practice at a United States Sub-Baccalaureate Technical College. International Journal for Research in Vocational Education and Training, 4 (2). Retrieved from http://www.ijrvet.net/index.php/IJRVET/article/view/166

Constance, T. Fischer. 1996. A humanistic and human science approach to emotion. Handbook of emotion, adult development, and aging, pages 67-82. Academic Press. Retrieved from 
https://www.sciencedirect.com/science/article/pii/B9780124649958500054

David C. Lindberg. 2010. The beginnings of Western Science: The European Scientific tradition in philosophical, religious, and institutional context, Prehistory to A.D. 1450. Second Edition. Chicago, USA: The University of Chicago Press..

Firdaus F. A \& Mariyat A. 2018. Humanistic approach in education according to Paulo Freire. At-Ta'dib, 12 ( 2). DOI: http://dx.doi.org/10.21111/at-tadib.v12i2.1264

Goldston, M. Jenice and Downey L. 2013. Your Science classroom: Becoming an Elementary Middle School Science Teacher, USA, SAGE Publication, Inc..

Hwa K. J \& Ju A.G. 2015. Effect of end-of-life care education using humanistic approach in Korea. Collegian, 22 (1), 91-97.

Johnstone, A. H . 1991. Why is science difficult to learn? Things are seldom what they seem. Journal of Computer Assisted Learning, 7 (2), 75-83. Retrieved from https://onlinelibrary.wiley.com/doi/abs/10.1111/j.1365-2729.1991.tb00230.x Retrieved from https://www.ncbi.nlm.nih.gov/pubmed/26285413

Kempa, R.F. Students' learning difficulties in Scierce: Causes and possible remedies. Enseñanza de Las Ciencias, 1991, 9 (2)

Lavrakas, Paul J (ed). 2008. Cross-Sectional Survey Design. Encyclopedia of Survey Research Methods. DOI: https://dx.doi.org/10.4135/9781412963947.n120

Linkedin Learning. Principle of teaching [Slide Presentation]. Retrieved from https://www.slideshare.net/missy1727/principles-of-teaching

Matthew. 2016. Philosophies of education: 3 Types of student-centered philosophies. Retrieved from https://www.theedadvocate.org/philosophies-education-3-types-student-centeredphilosophies/

Millar, Robin. (2008) . Why is science hard to learn? Journal of Computer Assisted Learnin. 7 (2), 66-74.

Retrieved from https://www.researchgate.net/publication/229507155

Ogunkola B. J \& Samuel D..Science Teachers' and students 'perceived difficult topics in the Integrated Science Curriculum of Lower Secondary Schools in Barbados. World Journal of Education, 2011, 1(2).

Postholm, May Britt. 2012. Teachers' professional development: A theoretical review. : Educational Research, 54 (4). Retrieved

https://www.tandfonline.com/doi/abs/10.1080/00131881.2012.734725

Roode, Dinant. 2016. Education Needs a Humanistic Approach. Retrieved from approach/ https://trenducation.wordpress.com/2016/04/25/education-needs-a-humanistic-

Sharp, Alastair. 2012. Humanistic approaches to learning. Encyclopedia of the Sciences of Learning. $\quad$ Retrieved from https://link.springer.com/referenceworkentry/10.1007\%2F978-1-4419-1428-6 530.

Shiau SJ and Chen CH. 2008. Reflection and critical thinking of humanistic care in medical education. Kaohsiung Journal of Medical Sciences, 24 (7), 67-372. Doi: 10.1016/S1607-551X(08)70134-7.

Tangney, Sue. 2014. Student-centred learning: A humanist perspective Teaching in Higher Education, 9 (3). Retrieved

https://www.tandfonline.com/doi/abs/10.1080/13562517.2013.860099 
Why do we need Scienc. University of Technology Sidney. [Power Point Slides]. Retreaved from: https://www.uts.edu.au/sites/default/files/cat)

Witt JD., Archer L, \& Moote J. 15/16-Year-old students' reasons for choosing and not choosing Physics at a Level. International Journal of Science and Mathematics Education, 2018, page 1-17. 